\title{
PENEGAKAN DAN PERLINDUNGAN HAK ASASI MANUSIA DI INDONESIA DALAM KONTEKS IMPLEMENTASI SILA KEMANUSIAAN YANG ADIL DAN BERADAB
}

\author{
Lilis Eka Lestari \\ Faculty of Law, Universitas Negeri Semarang (UNNES) \\ Jalan Raya Sekaran, Gedung K Lantai 1, Gunungpati Semarang \\ Email: lilisekalestari@gmail.com
}

Ridwan Arifin

Department of Criminal Law, Faculty of Law, Universitas Negeri Semarang (UNNES)

Legal Aid Center, Faculty of Law UNNES

Jalan Raya Sekaran, Gedung K Lantai 1, Gunungpati Semarang

Email: ridwan.arifin@mail.unnes.ac.id

\begin{abstract}
ABSTRAK
Hak asasi manusia yaitu hak yang dimiliki oleh manusia sebagai makhluk ciptaan tuhan. Hak asasi manusia telah menempuh perjalanan yang jauh untuk berjuang demi mendapatkan keadilan bagi manusia di seluruh dunia. Secara historis, usaha-usaha yang ditempuh untuk memecahkan persoalan kemanusiaan telah dilaksanakan sejak lama di dunia, dan tidak ada seorangpun yang mengetahui secara pasti sejak kapan hak asasi manusia mulai diperjuangkan. Kronologis konseptualisasi penegakan HAM yang diakui secara yuridis-formaldiawali dengan munculnya perjanjian Agung (Magna Charta) di Inggris pada 15 juni 1215, selanjutnya Petition of Rights di Inggris tahun 1628 yang juga dikenal dengan the Great of the Liberties of England, Deklarasi kemerdekaan Amerika Serikat pada 6 Juli 1776, Deklarasi hak-hak asasi manusia dan negara (Declaration des Droits de I'Homme et du Citoyen/Declaration of the Rights of Man and of the Citizen) di Prancis tahun 1789, Deklarasi Universal tentang hak asasi manusia (Universal Declaration of Human Rights/UDHR). Penegakanan hak asasi manusia merupakan cerminan atau perwujudan dari sila pancasila yang kedua yaitu kemanusiaan yang adil dan beradap. Penegakan hak asasi manusia terjadi karena adanya pelanggaran hukum yang dilakukan. Penegakan dan perlindungan hak asasi manusia di Indonesia mengalami kemajuan pada tanggal 06 Nomber 2000, di mana Dewan Perwakilan Rakyat (DPR) mengesahkan Undang-undang Nomor 26 Tahun 2000 mengenai Pengadilan Hak Asasi Manusia (HAM) yang diundangkan pada tanggal 23 November 2000. Pembentukan Komnas Ham dan Pengadilan HAM juga merupakan sebuah kemajuan dalam penegakan dan pengadilan tentang hak asasi manusia di Indonesia. Pancasila pada hakikatnya merupakan sistem nilai yang berasal dari nilai-nilai luhur kebudayaan bangsa Indonesia yang berkembang sepanjang sejarah, dan berakar dari kebudayaan Indonesia. Penegakan hak asasi manusia adalah tugas seluruh lapisan masyarakat, bukan hanya tugas bagi lembaga negara saja. Semua lapisan masyarakat tersebut diharapkan dapat berkerjasama dan saling membantu dalam menegakkan hak asasi manusia demi tercpapainya perwujudan sila Kemanusiaan yang adil dan beradab dan terciptanya masyarakat yang sejahtera.
\end{abstract}


Kata Kunci : Perlindungan, Penegakan, Hak Asasi Manusia, Indonesia, Pancasila

\begin{abstract}
Human rights are rights owned by humans as creatures of God. Human rights have traveled a long way to fight for justice for humans throughout the world. Historically, the efforts taken to solve humanitarian problems have been implemented for a long time in the world, and no one knows for sure since when human rights began to be fought for. Chronology of the conceptualization of human rights enforcement that was recognized legally-formally beginning with the emergence of the Great Agreement (Magna Charta) in England on 15 June 1215, then the Petition of Rights in England in 1628 which was also known as the Great of the Liberties of England. July 6, 1776, Declaration of human rights and state (Declaration des Droits de I'Homme et du Citoyen / Declaration of Rights of Man and of the Citizen) in France in 1789, Universal Declaration of human rights (Universal Declaration of Human Rights / UDHR). Enforcement of human rights is a reflection or manifestation of the second Pancasila precept, namely just and humanitarian humanity. Enforcement of human rights occurs because of legal violations. Enforcement and protection of human rights in Indonesia made progress on 6 November 2000, where the House of Representatives (DPR) passed Law Number 26 of 2000 concerning the Human Rights Court (HAM) promulgated on 23 November 2000. Establishment of the National Commission Ham and the Human Rights Court are also advances in the enforcement and trial of human rights in Indonesia. Pancasila is essentially a system of values that originates from the noble values of Indonesian culture that developed throughout history, and are rooted in Indonesian culture. Enforcement of human rights is the duty of all levels of society, not just the task of state institutions. All levels of society are expected to be able to collaborate and help each other in upholding human rights in order to achieve the realization of the principle of just and civilized Humanity and the creation of a prosperous society.
\end{abstract}

Keywords: Protection, Enforcement, Human Rights, Indonesia, Pancasila

\section{Pendahuluan}

Pancasila adalah dasar dari negara Indonesia yang lahir dan tumbuh dalam kepribadian bangsa yang merupakan bentuk dari sikap dan kepribadian bangsa Indonesia. Pancasila dijadikan sebagai pandangan hidup oleh bangsa Indonesia dan sekaligus sebagai ideologi negara. Sebagai ideologi negara Indonesia, pancasila mengandung nilainilai dan gagasan-gagasan dasar yang dapat dilihat melalui perilaku, sikap, dan kepribadian bangsa Indonesia. Nilai-nilai yang terkandung dalam pancasila tersebut bersifat dinamis, yang artinya upaya pengembangan sesuai dengan perkembangan atau perubahan dan tuntutan masyarakat bukan sesuatu yang tabu yang membuat nilai-nilai dasar tersebut menjadi beku, kaku, dan melahirkan sifat fanatik yang tidak logis. Pancasila sebagai ideologi negara memiliki kekhasan yang membedakannya dengan ideologi negara lainnya, hal ini karena pancasila membawakan nilainilai tertentu yang digali dari realitas sosio budaya bangsa Indonesia. 
Kekhasan tersebut dapat dilihat dari keyakinan dari adanya Tuhan Yang Maha Esa, yang membawa konsekuensi keimanan dan ketaqwaan kepada Tuhan Yang Maha Esa. Selanjutnya juga dapat terlihat dalam penghargaan akan harkat dan martabat kemanusiaan, yang diwujudkan dalam penghargaan terhadap hak asasi manusia dengan memperhatikan prinsip keseimbangan antara hak dan kewajiban. Kekhasan yang lain adalah bahwa ideologi pancasila selalu menjunjung tinggi persatuan bangsa dengan menempatkan terwujudnya persatuan bangsa di atas kepentingan individu, kelompok, serta golongan. Selanjutnya yaitu kehidupan bermasyarakat dan bernegara yang didasarkan pada prinpip demokrasi dengan penentuan keputusan bersama yang diupayakan sejauh mungkin melalui adanya musyawarah untuk mendapatkan kata mufakat. Kekhasan yang terakhir adalah keinginan untuk mewujudkan keadilan dalam kehidupan bersama seluruh warga masyarakat Indonesia.

Pancasila pada hakikatnya adalah sistem nilai yang berasal dari nilai-nilai luhur kebudayaan bangsa Indonesia yang berkembang sepanjang sejarah, dan berakar dari kebudayaan Indonesia. Sila-sila pancasila memiliki nilai-nilai yang sangat penting bagi kehidupan bangsa Indonesia. Sila yang pertama yaitu Ketuhanan Yang Maha Esa yang mana sila ini mempunyai arti bahwa semua masyarakat Indonesia selalu bertaqwa kepada tuhannya dan bebas untuk memeluk agama yang dipercayainya. Sila yang kedua yaitu kemanusiaan yang adil dan beradab yang mana menunjukkan bahwa bangsa Indonesia selalu menghormati harkat martabat manusia dalam wujud hak asasi manusia yang ditegakkan oleh negara Indonesia sebagai negara hukum. Sila yang ketiga adalah persatuan yang adil dan beradab yang memiliki arti bahwa masyarkat Indonesia selalu yang menjunjung tinggi persatuan bangsa untuk mewujudkan cita-cita negara Indonesia. Sil yang ke empat adalah kerakyatan yang dipimpin oleh hikmat kebijaksanaan dalam permusyawaratan perwakilan yang mempunyai arti bahwa masyarakat Indonesia selalu mengambil keputusan melalui musyawarah yang melibatkan semua masyarakat Indonesia. Sila yang terakhir adalah keadilan sosial bagi seluruh rakyat Indonesia, yang mana setiap masyarakat Indonesia berhak mendapatkan keadilan dan tidak adanya diskriminasi dalam pelaksanaannya. Nilai-nilai dari sila-sila pancasila ini dijadikan sebagai pedoman hidup berbangsa dan bernegara.

Sebagai negara hukum Indonesia selalu mengedepankan kesejahteraan rakyatnya yang mana inti dari negara Indonesia sebagai negara hukum dapat diidentifikasikan dengan tunduknya rakyat dan penguasa dengan hukum yang ada dan berlaku. Negara Indonesi sebagai negara hukum memiliki ciri yang sangat kuat diantaranya, pancasila menjiwai setiap peraturan hukum dan pelaksanaannya, asas kekeluargaan merupakan titik tolak negara hukum Indonesia, peradilan yang bebas dan tidak dipengaruhi kekuatan, partisipasi warga masyarakat secara luas, dan pengakuan serta perlindungan terhadap hak asasi manusia. Hak asasi manusia adalah hak yang dimiliki oleh manusia sebagai makhluk ciptaan tuhan. Hak asasi manusia merupakan sebuah tiang yang sangat penting dalam menopang tegaknya sebuah negara demokrasi. 
Pemahaman hak asasi manusia bagi bangsa Indonesia sangtalah penting di tanamkan bagi semua masyarakat yang ada di Indonesia. Hak asasi manusia sebagai anugerah dari Tuhan Yang Maha Esa melekat pada diri manusia, bersifat universal, kodrati, dan abadi, yang berkaitan dengan harkat dan martabat manusia. Setiap manusia diakui dan dihormati dengan hak asasi manusia tanpa membedakan warna kulit, jenis kelamin, kebangsaan, agama, usia, pandangan politik, status sosial, dan bahasa daerah. Bangsa Indonesia menyadari bahwa hak asasi manusia bersifat historis dan dinamis yang mana pelaksanaannya berkembang dalam kehidupan berbangsa, bernegara, dan bermasyarakat. Pentingnya hak asasi manusia bagi seluruh rakyat Indonesia tentunya memerlukan perlindungan hukum, perlindungan hukum tentang hak asasi manusia ini diatur dalam Undang-Undang Nomor 39 Tahun 1999 tentang hak asasi manusia. berkaitan dengan perlindungan hak asasi manusia warga negara Indonesia, Majelis Permusyawaratan Rakyat (MPR) dalam ST tahun 2001 memutuskan untuk mengadakan/memasukkan perubahan mengenai pasal-pasal yang berkaitan dengan hak asasi manusia dalam perubahan ketiga UUD 1945, hal ini bertujuan untuk semakin dihormati dan ditegakkannya hak asasi manusia di Indonesia.

Penegakanan hak asasi manusia tentunya merupakan cerminan atau perwujudan dari sila pancasila yang kedua yaitu kemanusiaan yang adil dan beradap. Penegakan dari hak asasi manusia ini bukan hanya dilakukan oleh para pejabat negara namun juga harus dilakukan dan dilaksanakan oleh semua rakyat Indonesia. Secara historis, usaha-usaha yang ditempuh untuk memcahkan persoalan kemanusiaan telah dilaksanakan sejak lama di dunia. Seluruh pemikiran yang telah berkembang menguatkan pendirian akan pentingnya citra diri seorang manusia, yaitu kemerdekaan dan kebebasannya. Kronologis konseptualisasi penegakan HAM yang diakui secara yuridis-formal adalah diawali dengan munculnya perjanjian Agung (Magna Charta) di Inggris pada 15 juni 1215, selanjutnya Petition of Rights di Inggris tahun 1628 yang juga dikenal dengan the Great of the Liberties of England, Deklarasi kemerdekaan Amerika Serikat pada 6 Juli 1776, Deklarasi hak-hak asasi manusia dan negara (Declaration des Droits de I'Homme et du Citoyen/Declaration of the Rights of Man and of the Citizen) di Prancis tahun 1789, Deklarasi Universal tentang hak asasi manusia (Universal Declaration of Human Rights/UDHR). ${ }^{1}$

Penegakan hak asasi manusia tentunya terjadi karena adanya pelanggaran hukum yang dilakukan oleh banyak orang. Kasus pelanggaran hukum yang paling besar di indonesia adalah adanya gerakan G30SPKI yang menewaskan sejumlah pejabat TNI yang dilakukan oleh PKI. Kasus pelanggaran hak asasi manusia yang ada di Indonesia salah satunya adalah Pelanggaran hak asasi manusia di Rumoh Geudong yang saat ini kasusnya berada di Kejaksaan Agung. ${ }^{2}$ Kasus ini

\footnotetext{
Majda El Muhtaj, 2013, Dimensi-dimensi HAM : Mengurai Hak Ekonomi, Sosial, dan Budaya, PT RajaGrafindo Persada, Depok, hlm. 8-10.

2 Yoga Sukmana, Pelanggaran HAM Rumoh Geudong : Tak ada alasan kejaksaan agung untuk diam, diakses dari https://nasional.kompas.com/read/2018/09/10/120 85951/pelanggaran-ham-rumoh-geudong-tak-adaalasan-kejaksaan-agung-untuk-diam, diakses pada kamis 6 desember 2018, pukul 15:28.
} 
telah ditangani sejak tahun 2013, dan kembali dilakukan penyelidikan oleh Komnas HAM. Kasus pelanggaran ini merupakan kasus pelanggaran hak asasi manusia di Aceh. Kasus pelanggaran hak asasi manusia lainnya adalah meninggalnya wartawan di lapas kelas II Kotabaru, Kalimantan Selatan. Kasus ini ditangani oleh Komnas HAM sejak 27 sampai dengan 30 Juni 2018. ${ }^{3}$ Pelanggaran HAM yang ada di Indonesia yang baru-baru ini terjadi yaitu pembunuhan pekerja di Papua. Kasus pelanggaran ini dianggap serius oleh Kepala KomnasHAM provinsi Papua. Pembunuhan pekerja yang mengerjakan proyek Jalan Trans Papua ini terjadi pada Minggu malam, 2 Desember 2018, pekerja dibunuh oleh sekelompok orang bersenjata. Kasus ini merupakan kasus pelanggaran HAM karena mengacu pada pasal 1ayat 6 Undang-undang Nomor 39 Tahun 1999 tentang hak asasi manusia. ${ }^{4}$

Hukum hak asasi manusia memang masih banyak terjadi pelanggaran dan penyimpangan namun di Indonesia telah adanya beberapa lembaga yang bertugas menegakkan dan mengatur tentang hukum hak asasi manusia. Lembaga ini antara lain adalah Komisi Nasional HAM (Komnas HAM) dan peradilan HAM, dengan adanya lembaga ini dapat dengan sendirinya terjadi peningkatan akan penegakan

3 FHR, Watawan tewas di lapas ada pelanggaran HAM diakses dari

https://www.cnnindonesia.com/nasional/2018072 7162850-12-317526/komnas-ham-soal-wartawantewas-di-lapas-ada-pelanggaran-ham\#, diakses pada kamis 6 desember 2018, pukul 15:33.

4 Ninis Chairunisa, Pembunuhan pekerja di Papua Komnas HAM "Pelanggaran Ham serius" diakses dari

https://nasional.tempo.co/read/1152380/pembunu han-pekerja-di-papua-komnas-ham-pelanggaranham-serius/full\&view=ok diakses pada tanggal 7 desember 2018, pukul 13:30. hukum hak asasi manusia yang ada di Indonesia. Perlindungan HAM ini mempunyai dua pijakan normatif berupa Undang-undang dan konstitusi serta komnas HAM dan peradilan HAM. Meskipun telah adanya lembaga yang mengatur tentang penegakan HAM, namun peran serta masyarakat dalam penegakan HAM di Indonesia sangatlah penting, karena merekalah yang menentukan bagaimana tegaknya hukum hak asasi manusia serta adanya perilaku yang menghargai hak asasi manusia atau justru menyimpang dan merugikan banyak orang.

\section{Pembahasan}

\section{A. Perkembangan Penegakan Hak Asasi Manusia}

Menurut Undang-undang Nomor 39 Tahun 1999 hak asasi manusia adalah seperangkat hak yang melekat pada hakikat yang melekat pada hakikat dan keberadaan manusia sebagai makhluk ciptaan Tuhan Yang Maha Esa dan yang merupakan anugera-Nya yang wajib dihormati, dijunjung tinggi, dan dilindungi oleh negara, pemerintah, hukum, dan setiap orang demi kehormatan serta perlindungan harkat dan martabat manusia. Seperti yang dijelaskan dalam Undang-undang Nomor 39 Tahun 1999 hak asasi manusia adalah hak yang melekat pada diri manusia sejak mereka lahir dan harus dihormati oleh setiap orang tidak terkecuali yang berkuasa. Berdasarkan hukumlah hak asasi manusia dapat memberikan kekuatan moral untuk melindungi dan juga menjamin martabat manusia, bukan atas dasar keadaan, kecenderungan politik tertentu, ataupun kehendak. ${ }^{5}$

5 Go Lisnawati, "Pendidikan tentang Pencegahan
Kekerasan terhadap Perempuan dalam Dimensi 
Hak asasi manusia telah menempuh perjalanan jauh untuk mendapatkan penegakan dan berjuang untuk mendapatkan keadilan bagi manusia di seluruh dunia. Tidak ada seorangpun yang mengetahui secara pasti sejak kapan hak asasi manusia mulai diperjuangkan, karena dari berbagai ajaran dalam kitab suci, perjungan terhadap hak asasi manusia telah ada sejak zaman dahulu kala sepeti halnya kisah atau ajaran agama te tang perjuangan nabi Ibrahim terhadap Raja Namrudz, kisah Nabi Musa yang melakukan perlawanan terhadap kejamnya raja Fir'aun dan juga masih banyak kisah lainnya yang pada hakikatnya merupakan kisah perjuangan memperjuangkan hak asasi manusia. ${ }^{6}$ Dilihat dari tinjauan historis, perjuangan tentang hak asasi manusia secara terpadu dimulai di inggris dengan adanya perumusan hak asasi manusia di piagam Magna Charta pada 15 Juni tahun 1215, sebagai bagian dari pemberontakan para baron terhadap raja John (saudara dari raja Richard Berhati Singa). Pada piagam ini terdapat isi pokok tentang kewenangan haruslah mewujudkan dan juga harus memberikan perlindungan atas hak-hak asasi baik hak ekonomi sosial, individu, dan politik. ${ }^{7}$ pemberontakan para baron ini dipicu adanya penetapan pajak yang sangat besar dan dipaksakannya baron untuk membolehkan anak-anak perempuannya untuk dinikahkan dengan rakyat biasa. $^{8}$ Piagam ini menunjukan adanya kemajuan yang pesat dalam konteks perjuangan hak

Kejahatan Siber", Jurnal Ilmu Hukum Pandecta, Vol. 9, No. 1, Januari 2014, hlm. 5.

6 Bahder Johan Nasution, 2017, Negara Hukum dan Hak Asasi Manusia, CV. Mandar Maju, Bandung, hlm. 132.

7 Ibid. hlm. 133

8 Majda El Muhtaj, Op. Cit, hlm. 9. asasi manusia, meskipun bagi penduduk secara umum piagam ini tidak begitu berarti. Dalam interpretasi generasi selanjutnya yaitu rakyat Inggris menafsirkan bahwa hak harus memperhatikan hak-hak rakyat dan tidak boleh dilanggar oleh raja, dan piagam ini mulai mengembangkan tradisi bahwa hukum adalah lebih tinggi dari Raja. Inggris kembali mempelopori pengakuan hak asasi manusia dengan adanya Petition of Rights tahun 1628. Petisi ini berisi tentang berbagai pernyataan mengenai hak-hak rakyat serta jaminannya kepada raja yang menjawabnya di hadapan sidang badan perwakilan, petisi ini berasal dari Dewan Perwakilan. Diperoleh penegasan mengenai hak-hak rakyat yang sebelumnya tidak adanya ketentuan sama sekali dari pertanyaan dan jawaban yang terdapat di piagam ini. Pada tahun 1670 ditetapkannya Hobeas Corpus Act, yang berisi tentang perintah atau titah Raja agar setiap orang yang ditahan segera dihadapkan kepada hakim dan diberikan tentang tuduhan mengapa ia ditahan. Hak-hak rakyat sedikit demi sedikit mulai dihormati secara luas. Dengan adanya piagam tersebut muncul prinsip hukum bahwa setiap orang yang ditahan harus atas perintah dari hakim. John Locke sebagai teoritikus Monarchi konstitusional memandang bahwa negara menerima kedaulatannya dari rakyat yang bertujuan untuk menjamin agar setiap warga negara tidak dilanggar hak-haknya dan tidak saling melanggar hak manusia satu dengan manusia yang lain antara warga negara yang satu dengan yang lain, sehingga warna negara bertugas untuk menyelenggarakan keteraturan dan ketentraman umum. Raja atau 
penyelenggara negara akan kehilangan haknya atas ketaatan warga negara dan warna negara berhak menentangnya apabila ia melanggar atau tidak mematuhi perundang-undnagan yang dibuat oleh parlemen. Perkembangan hak asasi manusia memperoleh inspirasi yang semakin kuat karena semangat hak asasi dan perlindungannya dengan dinyatakan sangat jelas dalam Virginia Bill of Rights dan Declaration of Independent pada tahun 1776. Deklarasi kemerdekaan Amerika Serikat pada tanggal 6 Juli 1776 ini berisi tentang, penegasan bahwa setiap orng dilahirkan dengan persamaan dan kebebasan dengan hak untuk hidup dan juga mengejar kebahagiaan, serta keharusan mengganti pemerintahan yang tidak mengindahkan ketentuan-ketentuan dasar. Selanjutnya pada tahun 1789 di Perancis dikeluarkannya Declaration des Droits de I'Homme et du Citoyen/Declaration of the Rights of Man and of the Citizen (Deklarasi hakhak asasi manusia dan warga negara), dalam deklarasi ini ada lima hak yang diadopsi yakni, propiete (kepemilikan harta), liberte (kebebasan), egalite (persamaan), securite (keamanan), resistence a l'oppression (perlawanan terhadap penindasan. Pada tahun 1948, munculah Deklarasi Universal tentang hak asasi manusia (Universal Declaration of Human Rights /UDHR). Deklarasi ini memuat pokok-pokok tentang, persamaan, kebebasan, hak-hak dalam perkawinan, pemilikan harta, pendidikan, hak kerja, dan kebebasan beragama termasuk pindah agama, ditambah dengan berbagai instrument lainnya yang datang susul-menyusul yang memperkaya eksistensi perlindungan hak asasi manusia sekaligus menjadi bahan rujukan yang tidak mungkin diabaikan. ${ }^{9}$

Perkembangan hak asasi manusia terjadi diseluruh dunia, termasuk juga di Asia yang merupakan benua di mana negara Indonesia berdiri. Perkembangan hak asasi manusia di Asia belum mempunyai piagam tentang hak asasi manusia seperti negara-negara Eropa, Afrika, maupun Amerika. Kuatnya tradisi dan agama-agama besar di kebanyakan negara-negara Asia menjadi alasan mengapa tidak adanya piagam, selain itu pengaruh agama dan tradisi menjadi pengaruh bagi pola pikir/pola tindak dan juga sikap sebagian besar dari negara-negara yang ada di Asia. Langkah-langkah yuridis yang diambil untuk mempercepat penghormatan atas hak asasi manusia yaitu, pada tahun 1928 di New Delhi pernah diselenggarakan Seminar on Approaches to Human Rights in Asia yang diselengarakan oleh United Nation University-Tokyo, Unesco-Paris dan Centre for Human Rights Education and Research New Delhi, dalam seminar ini diambil beberapa kesimpulan yaitu, hubungan hak asasi manusia dengan kemiskinan, antara lain ditegaskan tentang peranan negara dan lembaga sosial dalam mengawasi pelanggaran hak asasi manusia, pelanggaran hak asasi manusia dalam masyarakat tidak mampu dalam dimensi regional dan internasional, dan hubungan antara gerakan kemerdekaan dan hak menentukan nasibnya sendiri dalam menegakkan hak asasi manusia. ${ }^{10}$ Simpulan yang selanjutnya adalah

9 United Nations, Human Rights : A Compilation of International, vol 1 (First Part) and (Second Part) (New York : United Nations, 2002).

10 A. Masyhur Effendi, Taufani S. Evandri, 2010, HAM dalam Dinamika/Dimensi Hukum, Politik, Ekonomi, dan Sosial, Ghalia Indonesia, Bogor, hlm. 129. 
hubungan hak asasi manusia, kebudayaan, dan tradisi keagamaan yang mana hubungannya adalah bagaimana cita-cita atau ide agam, tradisi, budaya dalam konsep yang terkait dengan hak asasi manusia dan relevan kesatuan sistem hukum dalam mengembangkan kelompok budaya atau agama dalam rangka menghormati hak-haknya. Simpulan yang ketiga yaitu hak asasi manusia dalam rangka sistem keimanan Asia yang meliputi, bagaimana peranan IPTEK dalam menjawab HAM agar dapat terjaminnya dengan baik, mempelajarai proses militarisasi dan otokrasi di Asia, mengembangkan hubungan hukum hak asasi manusia dengan hukum humaniter daam rangka menggalakkan hak asasi manusia, disusun beberapa rekomendasi, baik ditunjukkan kepada UNESCO maupun UNO.

Upaya yang kedua yaitu Singapore White Paper on Shared Vaues tahun 1991. Hal ini lahir karena adanya anggapan bahwa generasi muda Singapura perlu ideologi sebagai pegangan yang dapat diterima oleh semua golongan masyarakat karena tidak bertentangan dengan agam dan juga tradisi masing-masing golongan. Singapore White Paper on Shared Vaues ini diterima pada Januari 1991, terdapat lima nilai yang terkandung di dalamnya yaitu kepentingan negara di atas kepentingan masyarakat di atas kepentingan pribadi, keluarga sebagai kesatuan dasar masyarakat, dukungan komunitas serta respek untuk individu, konsensus bukan konflik, dan harmoni rasial dan religius. Upaya selanjutnya yaitu, tanggal 26-28 Januari 1993 diselenggarakan satu lokakarya tentang hak asasi manusia di Asia Pasifik, pada bulan April 1993 diselenggarakan konferensi HAM untuk kawasan Asia
Pasifik di Bangkok dan berhasil menyusun satu deklarasi, yang diberi nama deklarasi Bangkok. Upaya yang terakhir adalah terbentuknya badan HAM ASEAN.

\section{B. Penegakan dan Perlindungan HAM di Indonesia}

Negara Indonesia adalah negara hukum yang selalu menjunjung tinggi keadilan dan juga kepastian hukum bagi seluruh masyarakatnya. Hukum diciptakan untuk mengendalikan dan mentertibkan masyarakat serta agar masing-masing subjek hukum dapat menjalankan kewajibannya dengan baik dan mendapatkan haknya. Philipus M. Hadjon mempunyai pendapat bahwa perlindungan hukum dibagi menjadi dua yaitu perlindungan hukum preventif dan perlindungan hukum respresif. Perlindungan hukum preventif bertujuan agar mencegah adanya sengketa. Perlindungan hukum represif bertujuan untuk menyelesaikan sengketa.

Penegakan hukum yaitu proses yang dilakukan agar tegak dan berfungsinya norma-norma hukum dalam kenyataan sebagai pedoman perilaku dalam lalu lintas atau hubungan hukum dalam kehidupan bermasyarakat dan bernegara. Hukum harus ditegakkan karena nilai-nilai keadilan yang terkandung di dalamnya sangat penting bagi kesejahteraan masyarakat.

Penegakan dan perlindungan tentang hak asasi manusia di Indonesia sangatlah penting bagi rakyatnya, karena hak asasi manusia berkaitan dengan harkat dan martabat manusia sebagai manusia seutuhnya. Hak asasi manusia di Indonesia sangat berhubungan berat dengan landasan negara Indonesia yaitu pancasila, yang 
mana tercantum dalam sila ke-dua. Hak asasi manusia di negara Indonesia sangat dijunjung tinggi, karena merupakan salah satu ciri dari negara Indonesia sebagai negara hukum yang selalu menjaga harkat dan martabat dari rakyat Indonesia. Oleh karena itu, penegakan dan perlindungan HAM di Indonesia sangat dijaga dan dijunjung tinggi. Penegakan dan perlindungan hak asasi manusia di Indonesia mengalami kemajuan pada tanggal 06 Nomber 2000, di mana Dewan Perwakilan Rakyat (DPR) mengesahkan Undang-undang Nomor 26 Tahun 2000 mengenai Pengadilan Hak Asasi Manusia (HAM) yang diundangkan pada tanggal 23 November 2000. Undang-undang ini menjadi dasar adanya pengadilan hak asasi manusia yang berwenang mengadili para pelaku pelanggaran hak asasi manusia berat. Undang-undang ini mengatur tentang beberapa kekhususan atau pengaturan yang berbeda dengan pengaturan dalam hukum acara pidana, perbedaan ini di mulai dari tahap penyelidikan oleh Komnas HAM, sampai pengaturan tentang majelis hakim yang komposisinya berbeda dengan pengadilan pengadilan biasa. Komposisi hakim terdiri dari lima orang yang mewajibkan tiga orang diantaranya adalah hakim ad hoc. ${ }^{11}$ Untuk menegakkan kebebasan manusia fundamental, sama dan tidak dapat dicabut hak yang dimiliki setiap manusia terlahir adalah kondisi penting, untuk mencapai yaitu dengan mempromosikan dan melindungi kepentingan sipil, ekonomi, politik, hak asasi manusia sosial dan budaya setiap manusia, pria dan anak. ${ }^{12}$ Hal tersebut

11 Bahder Johan Nasution, Op. Cit, hlm. 263.

12 Prince Zeid Ra'ad, Al Hussein, "Klatsky Endowed Lecture Presented by the U.N. High bertujuan agar proses pengadilan dapat berjalan dengan kompeten dan fair dalam menyelesaikan kasus-kasus pelanggaran hak asasi manusia berat. Undang-undang Nomor 26 Tahun 2000 tentang pengadilan hak asasi manusia dijalankan dengan dibentuknya pengadilan hak asasi manusia ad hoc untuk mengadili kasus pelanggaran hak asasi manusia berat yang terjadi di Timor Timur. Pada era reformasi dikeluarkan peraturan pemerintah penganti Undang-undang (Perpu) Nomor 1 Tahun 1999 tentang pengadilan hak asasi manusia, namun peraturan perundang-undangan tersebut tidak disetujui oleh DPR dan dicabut. Penegakan hak asasi manusia diatur dalam Undang-undang Nomor 39 Tahun 1999. Dalam Undang-undang Nomor 39 Tahun 1999 di dalamnya terdapat hak dasar manusia yang dijelaskan terperinci dalam BAB III dengan judul HAM dan dasar kebebasan dasar manusia dalam pasal 9-66. ${ }^{13}$ Permasalahan hak asasi manusia sebagai pembangunan sosial juga telah diatur oleh pemerintah yang mana diatur dalam Peraturan Pemerintah Nomor 7 Tahun 2005. ${ }^{14}$

Selain kelengkapan dari peraturan perundang-undangan penegak hukum juga menjadi penentu dari penegakan hukum hak asasi manusia di Indonesia, salah satunya adalah Mahkamah Konstitusi (MK). Putusan Mahkamah Konstitusi dapat mempengaruhi

Commissioner for Human Rights", Internationanl Law: Case Western Reserve Journal. hlm. 242.

13 Ibrahim Anis, "Telaah Yuridis Perkembangan Hukum Positif tentang Hak Asasi Manusia (HAM) di Indonesia. Lumajang, Jurnal Hukum Argumentum, Vol. 9, No. 2, 2010, hlm. 6.

14 Triwarti Rahayu, Suryadi, "Penerapan Hak Asasi Manusia sebagai Pembentuk Karakter dalam Pembelajaran Bahasa Indonesia pada Sekolah Menengah Atas di Kota Yogyakarta" , Jurnal Penelitian, Vol. 10, hlm. 14. 
pelaksanaan penegakan hak asasi manusia, diantaranya yaitu Putusan No 011-017/PUU-VIII/ 2003 tentang pengujian Undang-Undang No 12/2003 tentang Pemilihan Umum Anggota Dewan Perwakilan Rakyat, Dewan Perwakilan Daerah, dan Dewan Perwakilan Rakyat Daerah, Putusan No 6-13-20/PUU-VIII/2010 tentang pengujian Undang-Undang No 16 tahun 2004 tentang Kejaksaan Republik Indonesia, Putusan No 55/PUUVIII/2010 tentang pengujian UndangUndang Nomor 18 Tahun 2004 tentang Perkebunan, Putusan No 27/PUUIX/2011 tentang pengujian UndangUndang No 13 Tahun 2003 tentang Ketenagakerjaan. ${ }^{15}$

Pelanggaran-pelanggaran hak asasi manusia berat yang terjadi di Indonesia kebanyakan dilakukan oleh rezim pemerintahan diantara lain yaitu, pembunuhan masal yang dilakukan oleh G-30SPKI pada tahun 1965-1966, pelanggaran hak asasi di Aceh dan Papua, penculikan dan pembunuhan misterius yang dikenal dengan Petrus, kasus Tanjung Priok, kasus Warsidi di Lampung, kasus penculikan aktivis demokratis, dan pelanggaran hak asasi manusia di Timor Timur setelah adanya jajak Pendapat.

Upaya yang dilakukan oleh negara Indonesia dalam penegakan hak asasi manusia dapat ditempuh melalui penyempurnaan produk-produk hukum dan perundang-undangan tentang hak asasi manusia, melakukan inventarisasi, mengevaluasi dan mengkaji semua produk hukum, KUHAP, KUHP yang tidak sesuai dengan hak asasi manusia,

15 Saldi Isra, "Peran Mahkamah Konstitusi dalam Penguatan Hak Asasi Manusia di Indonesia", Jurnal konstitusi, Vol. 11, No. 3, September 2014, hlm. 421. mengembangkan

kapasitas kelembagaan pada instansi-instansi peradilan dan instansi lainnya yang berhubungan dengan peradilan dan penegakan hak asasi manusia, sosialisasi tentang pentingnya hak asasi manusia kepada masyarakat, dan kerjasama perlindungan hukum dengan segala aspek dan lapisan masyarakat.

\section{Penegakan dan Perlindungan HAM Sebagai Perwujudan Kemanusiaan yang Adil dan Beradab}

Pancasila adalah landasan dari negara Indonesia yang menjadi dasar dari cita-cita bangsa Indonesia untuk meraih tujuan negara. Nilai-nilai dalam sila-sila pancasila lahir dan tumbuh dalam kepribadian bangsa Indonesia yang merupakan perwujudan dari adanya budaya dan tradisi masyarakat Indonesia. Pancasila dalam setiap silanya mengandung nilai-nilai luhur yang patut dijunjung tinggi oleh bangsa dan masyarkat Indonesia. Sila yang pertama berbunyi Ketuhanan Yang Maha Esa mengandung nilai arti keyakinan dan pengakuan yang diwujudkan dalam bentuk perbuatan terhadap Tuhan Yang Maha Esa. Nilai ini mempunyai arti memberikan kebebasan kepada pemeluk agama sesuai dengan keyakinan masingmasing, tidak adanya unsur paksaan, dan antar penganut agama harus saling menghormati dan berkerjasama. ${ }^{16}$ Melalui sila ini dimensi spiritualitas keberagaman lebih terasa promising and challengin dan tidak hanya terfokus pada dimensi formalitas lahiriyah kelembagaan agama saja. Nilai Kemanusiaan yang adil dan beradab mengandung arti tentang kesadaran

16 M. Amin Abdullah, "Etika dan Dialog Antara Agama : Perspektif Islam", Jurnal Ulumul Qur'an, Vol. IV, No. 4, 1993, hlm. 21. 
dan sikap serta perilaku yang sesuai dengan nilai moral dalam hidup bersama berdasarkan atas tuntutan mutlak dari hati nurani dengan memperlakukan sesuatu hal sebagaimana mestinya. Perwujudan nilai kemanusiaan yang adil dan beradab adalah pengakuan hak asasi manusia, yang mana manusia harus diakui dan diperlakukan sebagaimana manusia seutuhnya sesuai dengan harkat dan martbatnya sebagai makhluk ciptaan Tuhan Yang Maha Esa. Nilai persatuan Indonesia mengandung arti usaha untuk mempersatukan bangsa dalam berkedaulatan rakyat untuk membina Nasionalisme dalam negara. Nilai ini merupakan suatu proses dimana untuk menuju terwujudnya Nasionalisme, dengan modal dasar nilai persatuan, semua warga negara Indonesia baik yang asli maupun keturunan asing dan dari macammacam suku bangsa dapat menjalin adanya kerjasama yang erat dalam wujud gotongroyong dan kebersamaan. Nilai kerakyatan yang dipimpin oleh hikmat dan kebijaksanaan dalam permusyawaratan perwakilan mengandung arti suatu pemerintahan rakyat dengan melalui badan-badan tertentu dalam menetapkan sesuatu peraturan ditempuh dengan adanya jalan musyawarah untuk mufakat atas dasar kebenaran dari Tuhan dan putusan akal harus sesuai dengan rasa kemanusiaan yang memperhatikan serta mempertimbangkan kehendak rakyat untuk mencapai kesejahteraan. Nilai keadilan sosial bagi seluruh rakyat Indonesia, makna yang terkandung dalam sila ini adalah suatu tata masyarakat adil dan makmur sejahtera lahirlah batiniah sehingga setiap warga negara mendapat segala sesuatu yang telah menjadi haknya sesuai dengan essensi adil dan beradab.

Hak asasi manusia merupakan perwujudan dari sila Kemanusiaan yang adil dan beradab. Hak asasi sangat di hormati dan dijunjung tinggi oleh nilai-nilai pancasila khususnya nilai sila ke dua, yang mana rasa sikap toleransi dan saling menghormati merupakan kebiasaan bangsa Indonesia yang tumbuh dan berkembang dalam kehidupan bangsa Indonesia.hak asasi manusia sebagai perwujudan sila yang kedua menempatkan hak setiap warga negara pada kedudukannya yang sama. Setiap manusia mempunyai kewajiban dan hak-hak yang sama untuk mendapatkan jaminan dan perlindungan undang-undang. Hak asasi manusia sebagai perwujudan sila yang kedua menempatkan manusia pada mana ia harus mendapatkan kedudukan yang sama terutama di bidang hukum, karena negara Indonesia merupakan negara hukum. Seperti apa yang dijelaskan, sebagai negara hukum hak asasi manusia sangat dihargai dan erlu ditegakkan di dalam pelaksanaan kenegaraan. Penegakan hak asasi manusia apabila terealisasi akan mewujudkan nilai dari sila yang kedua. Apabila penegakan hak asasi manusia terealisasi maka kehidupan masyarakat Indonesia dapat dipastikan akan sejahtera dan tidak akan ada keresahan yang timbul karena adanya pelanggaran hak asasi manusia. Hal ini selaras dengan apa yang telah di bahas dalam pasal 28 a-j, bahwa terdapat semua hakhak dasar manusia sebagai manusia seutuhnya.

Penegakan hak asasi manusia merupakan perwujudan dari sila kemanusiaan yang beradap yang memberikan kesamaan perlakuan dan harkat martabat kepada semua 
masyarakat Indonesia tanpa terkecuali, tanpa melihat apa jabatan, apa warna kulit, apa agamanya, dan masih banyak lagi. Penegakan hak asasi manusia dapat ditegakkan dengan diperkuatnya karakter rakyat sebagai faktor penting penegakan hak asasi manusia di Indonesia dengan nilai-nilai sila Pancasila. Apabila ditelaah lebih secara lebih dalam hak asasi manusia dapat tercermin dalam setiap nilai-nilai dari sila-sila pancasila. Mulai dari kebebasan memluk agama, hak untuk mendapatkan kehormatan dari manusia lainnya, hak untuk ikut mepersatukan bangsa, hak untuk kebebasan mengemukakan pendapat dan juga hak untuk mendapatkan keadilan tanpa terkecuali. Apabila penegakan hukum hak asasi manusia di Indonesia tidak ditegakkan kekacauan akan terjadi dimana-mana, dan juga tidak akan adanya peri kemanusiaan yang dijunjung tinggi oleh bangsa Indonesia.

\section{Kesimpulan}

Kesejarahan penegakan hak asasi manusia telah di mulai sejak zaman dahulu. Penegakan atau perjuangan akan nilai kemanusiaan di dunia dimulai dari adanya di piagam Magna Charta pada 15 Juni tahun 1215 sampai dengan Deklarasi Universal tentang hak asasi manusia (Universal Declaration of Human Rights/UDHR). Perkembangan hak asasi manusia berkembang di seluruh dunia, begitupun juga di Asia. Perkembangan penegakan hak asasi manusia di Asia dipengaruhi oleh kuatnya adat istiadat dan agama yang ada di dalam masyarakatnya. Langkahlangkah yuridis yang ditempuh untuk memperjuangkan hak asasi manusia di Asia yaitu, pada tahun 1928 di New Delhi pernah diselenggarakan Seminar on Approaches to Human Rights in Asia yang diselengarakan oleh United Nation University-Tokyo, Unesco-Paris dan Centre for Human Rights Education and Research New Delhi, hingga dibentuknya badan HAM ASEAN. Penegakan hak asasi manusia yang dilakukakan di Indonesia mengalami kemajuan pada tanggal 06 Nomber 2000, di mana Dewan Perwakilan Rakyat (DPR) mengesahkan Undangundang Nomor 26 Tahun 2000 mengenai Pengadilan Hak Asasi Manusia (HAM). Untuk menjalankan penegakan hak asasi manusia di Indonesia dibentuklah Undang-undang Nomor 39 Tahun 1999 tentang perlindungan hak asasi manusia. penegakan dan pengadilan hak asasi manusia memerlukan dukungan dari semua komponen mulai dari kelengakapan perlindungan hingga partisipasi dari semua lapisan masyarakat. Hak asasi manusia merupakan perwujudan dari sila kedua pancasila yaitu Kemanusiaan yang adil dan beradab, sehingga hak asasi manusia haruslah didapatkan oleh semua masyarakat Indonesia tanpa terkecuali.

\section{Daftar Pustaka \\ Buku}

Effendi, A. Masyhur, dkk. (2010). HAM dalam Dinamika/Dimensi Hukum, Politik, Ekonomi, dan Sosial, Ghalia Indonesia. Bogor : Ghalia Indonesia.

El Muhtaj, Majda. (2013). Dimensidimensi HAM : Mengurai Hak Ekonomi, Sosial, dan Budaya. Depok : PT RajaGrafindo Persada.

Johan Nasution, Bahder. (2017). Negara Hukum dan Hak Asasi Manusia. Bandung : CV. Mandar Maju.

Rahardjo, Satjipto. (2014). Ilmu Hukum.Bandung : PT Citra Aditya Bakti. 
Sularto, RB. (2018). Pengadilan HAM (AD HOC)Telaah Kelembagaan dan Kebijakan Hukum. Jakarta : Sinar Grafika.

Suprayogi, dkk. (2018). Pendidikan Pancasila.Semarang : UNNES PRESS.

\section{Artikel Jurnal}

Abbas, Jaffar. et al. (2018). "The Moderating Role of Gender Inequality and Age Among Emotional Intelligence, Homesickness and Development of Mood Swings in University Students", Vol. 15, No. 5, hlm. 359.

Abdullah, M. Amin. (1993). “Etika dan Dialog Antara Agama : Perspektif Islam", Jurnal Ulumul Qur'an, Vol. IV, No. 4, hlm. 21.

Anis, Ibrahim. (2010). “Telaah Yuridis Perkembangan Hukum Positif tentang Hak Asasi Manusia (HAM) di Indonesia. Lumajang, Jurnal Hukum Argumentum, Vol. 9, No. 2, hlm. 6.

Bruce, John W.,et.al, (2006). Land Law Reform : Achieving Development Policy Objec_ves, The World Bank, Washington DC.

Daalen, Edwar Van \& Mabillard, Nicolas. (2018). "Human Rights in Translation : Bolivia's Law 548, Working Children's Movements, and the Globals Child Labour Regime, The International Journal of Human Rights, Vol. 22, No. 9, hlm. 27.

Isra, Saldi. (2014). “Peran Mahkamah Konstitusi dalam Penguatan Hak Asasi Manusia di Indonesia", Jurnal konstitusi, Vol. 11, No. 2014, hlm. 421.

Kamaruddin. (2013). "Dimensi sila "Ketuhanan yang Maha Esa" dalam Perspektif HAM Islam", Jurnal Agama dan Hak Asasi Manusia, Vol. 3, No. 1, hlm.177.

Kuijer, Martin. (2018). “The Challengin Relationship Between the European
Convention on Human Rights and the EU Legal Order : Consequences of a Deleyed Accession", The International Journal of Human Rights, Vol. 22, No. 9, hlm. 3.

Lisnawati, Go. (2014). "Pendidikan tentang Pencegahan Kekerasan terhadap Perempuan dalam Dimensi Kejahatan Siber", Jurnal Ilmu Hukum Pandecta, Vol. 9, No. 1, hlm. 5.

Luthfan, Mukhamad Setiaji \& Ibrahim, Aminullah. (2017). "Kajian Hak Asasi Manusia dalam Negara the Rule of Law : Antara Hukum Progresif dan Hukum Positif", Jurnal Lex Scientia Law Review, Vol. 1, No. 1, 2017, hlm. 76.

Mulya Lubis, Todung. "Putusan Mahkamah Konstitusi Perkara No 1117/PUU-I/2003 dari Perspektif Hukum Hak Asasi Manusia Internasional",Jurnal Konstitusi, vol 1 No. 12004, hlm. 19.

Prince Zeid Ra'ad, Al Hussein. "Klatsky Endowed Lecture Presented by the U.N. High Commissioner for Human Rights", Internationanl Law: Case Western Reserve Journal. hlm. 242.

Rahayu, Triwati, Suryadi. "Penerapan Hak Asasi Manusia sebagai Pembentuk Karakter dalam Pembelajaran Bahasa Indonesia pada Sekolah Menengah Atas di Kota Yogyakarta", Jurnal Penelitian, Vol. 10, hlm. 14.

United Nations, Human Rights. (2002). "A Compilation of International", United Nations, vol 1 (First Part) and (Second Part).

Yuliarso, Kunto Kurniawan \& Prajarto, Nunung. (2005). “Hak Asasi Manusia (HAM) di Indonesia : Menuju Democratic Governances", Jurnal Ilmu Sosial dan Ilmu Politik, Vol.8, No.3, hlm. 293. 


\section{Online :}

https://nasional.kompas.com/read/20

18/09/10/12085951/pelanggaran-

ham-rumoh-geudong-tak-ada-alasankejaksaan-agung-untuk-diam, diakses pada kamis 6 desember 2018, pukul 15:28.

https://nasional.tempo.co/read/115238

$0 /$ pembunuhan-pekerja-di-papuakomnas-ham-pelanggaran-hamserius $/$ full\&view $=$ ok

https://www.cnnindonesia.com/nasio nal/20180727162850-12-

317526/komnas-ham-soal-wartawantewas-di-lapas-ada-pelanggaran-

ham\#

\section{Peraturan Perundang-undangan}

Republik Indonesia. 1999. Undangundang Nomor 39 Tahun 1999 tentang Hak Asasi Manusia. Lembaran Negara RI Nomor 3886. Jakarta. Sekretariat Negara.

Republik Indonesia. 2000. Undangundang Nomor 26 Tahun 2000 tentang Pengadilan Hak Asasi Manusia. Lembaran Negara RI 2000 Nomor 208. Jakarta. Sekretariat Negara.

Republik Indonesia. 2003. Undangundang Nomor 13 Tahun 2003 tentang Ketenagakerjaan. Lembaran Negara RI Nomor 4279. 